\title{
RELATIONSHIP OF ISOANTIGENS OF RABBIT SPERMATOZOA TO ERYTHROCYTIC ANTIGENS
}

\author{
M. C. PADMA* \\ Division of Dairy Chemistry, Southern Regional Station, \\ National Dairy Research Institute, Adugodi, Bangalore-30, India
}

(Received 7th August 1970, accepted 1st March 1972)

\begin{abstract}
Summary. By cross matching the bloods of eighteen rabbits, the relative blood group pattern was determined. Further, by using three typing sera (anti-A, $-\mathrm{D}$, and $-\mathrm{F}$ sera) the presence of these antigens on red cells was determined. The agglutination pattern of the sera of the eighteen rabbits with spermatozoa from seven rabbits of the group and the absorption of positive sera with red cells and spermatozoa showed that no common antigens existed between red cells and spermatozoa. The absence of common antigen between red cells and spermatozoa in rabbits was further confirmed by mixed agglutination of these two kinds of cells using natural haemagglutinins as well as specific blood typing immune sera.
\end{abstract}

\section{INTRODUCTION}

Landsteiner \& Levine (1926) were the first to demonstrate the presence of a common antigen in human beings between red blood cells and spermatozoa. They could absorb blood group antibodies specific to human antigens $\mathrm{A}$ and $\mathrm{B}$ with parental spermatozoa. Edwards, Ferguson \& Coombs (1964) later established that the human sperm membrane possessed 'species-specific' antigens in common with red cells. The presence of other isoantigens of human blood groups $\mathrm{M}, \mathrm{N}$ and $\mathrm{Tj}$ a were also shown to be present on the homologous spermatozoa. Boettcher (1965) and Edwards et al. (1964) revealed that, in humans, only those individuals who were secretors of their blood group substances possessed them on their gametes. Majsky \& Hraba (1960) demonstrated one more blood group substance $\mathrm{D}\left(\mathbf{R} \mathbf{h}_{0}\right)$ on human spermatozoa. In cattle, Docton, Ferguson, Lazear \& Ely (1952), using thirty-two specific immune sera detected the majority of the blood group antigens on the homologous spermatozoa. In some cattle, they showed that the sheep antisera prepared against bovine spermatozoa lysed homologous red blood cells. Negative results were reported by Matousek (1964) in his experimental bulls of Red Spotted breed. Using twenty-seven specific immune sera for bovine blood groups, he failed to detect common antigens between the red cells and spermatozoa of the corresponding male. His negative results were confirmed by Schmidt (1960). One

\footnotetext{
* Present address: Department of Genetics, Osmania University, Tarnaka, Hyderabad-7, India.
} 
antigen of the $\mathrm{J}$ blood group system has been shown to be present on the spermatozoa of certain bulls (Padma, 1969).

No such information is available regarding the relationship of blood group substances to the sperm antigens in rabbits. In the following paper, an attempt is made to study the presence of common antigens between erythrocytes and spermatozoa.

\section{MATERIALS AND METHODS}

\section{Selection of animals}

Eighteen rabbits (ten males and eight females) of mixed variety were selected in a random fashion. The animals were fed on lucerne grass, milk and Bengal gram (Cicer arietinum -a legume, rich in protein) with adequate water.

\section{Bleeding of animals}

Blood obtained by cardiac puncture was collected into Rous-Turner Solution ( 5 vol. of $5.4 \%$ glucose solution mixed with 2 vol. of $3.8 \%$ sodium citrate solution) in $1: 3$ ratio and preserved at $4^{\circ} \mathrm{C}$. The sera were inactivated at $56^{\circ} \mathrm{C}$ for $30 \mathrm{~min}$.

\section{Slide agglutination}

Essentially, the methods of Schiff \& Boyd (1942) and Kabat (1956) were followed. Undiluted inactivated serum $(0.25$ to $0.3 \mathrm{ml})$ was mixed with $0.05 \mathrm{ml}$ of a $2 \%$ red cell suspension on a microscope slide, and incubated at room temperature $\left(28^{\circ} \mathrm{C}\right.$ usually) for $30 \mathrm{~min}$. The slides were examined for agglutination (graded at $\mathrm{I}+, 2+, 3+, 4+$ or negative) both by macroscopic and microscopic examination, depending on the intensity of agglutination. All the eighteen sera were tested simultaneously on the same day using the same cell preparation and with controls.

\section{Tube agglutination}

This closely resembled the slide agglutination method; $0.5 \mathrm{ml}$ undiluted serum was mixed with $0.1 \mathrm{ml}$ of a $2 \%$ red cell suspension, and incubated at room temperature for $30 \mathrm{~min}$. After centrifuging, the cell clumps were read by naked eye and microscopically.

\section{Preparation of the sperm suspension}

Rabbit semen was collected with the help of an artificial vagina constructed on the model of Macirone \& Walton (1938). Never more than $0.5 \mathrm{ml}$ semen could be collected per ejaculate. Smith (1949) reported that maximum titre and real agglutination only occurred at $\mathrm{pH}$ values around neutrality when the motility of the spermatozoa was not affected. In the present test, the diluent used was phosphate-buffered saline at $\mathrm{pH} 7 \cdot 1$ to 7.2. The spermatozoa were washed thrice in saline (at $1000 \mathrm{rev} / \mathrm{min}$ for $10 \mathrm{~min}$ ). Prolonged centrifugation at higher speeds and for longer periods caused loss of sperm motility.

\section{Sperm agglutination tests}

The procedure was very similar to that for red cell agglutination. The concentration of the spermatozoa in suspension was between 2.0 and $3 \cdot 0 \times 10^{8} / \mathrm{ml}$. 
Live, motile, fresh spermatozoa (not more than $2 \mathrm{hr}$ old) at room temperature were always used for every test involving spermatozoa. The final sperm count represented an average of four readings.

Anti- $A,-D$ and $-F$ blood typing immune sera

The procedure of agglutination employing the three specific immune sera anti-A, $-\mathrm{D}$, and $-\mathrm{F}$ was the same as above.

\section{Absorption of sera}

Sera $(5 \mathrm{ml})$ were mixed with $2 \mathrm{ml}$ of a 15 to $20 \%$ red cell suspension and were incubated at $37^{\circ} \mathrm{C}$ for $1 \mathrm{hr}$. The sera were checked for complete absorption later. A similar procedure was followed for absorption with spermatozoa.

\section{Mixed agglutination}

Slight modifications of the methods of Coombs, Bedford \& Rouillard (1956) and of Edwards et al. (1964) for mixed agglutination reaction were followed. Separation of the antigen (spermatozoa)-antibody aggregate was not done before mixing with the red cells. Undiluted heat-inactivated serum $(0.4 \mathrm{ml})$, $2 \%$ red cell suspension $(0.05 \mathrm{ml})$, and $0.05 \mathrm{ml}$ of sperm suspension $(2.0$ to $3.0 \times$ $10^{8} / \mathrm{ml}$ ) were mixed well and the slides were incubated at room temperature for $30 \mathrm{~min}$. Saline controls of red cells and spermatozoa were run simultaneously.

\section{RESULTS}

Cross matching of the blood types of the eighteen rabbits

To ascertain the initial blood group antigen pattern, cross matching was carried out. The three independent tests using different reagents each time gave comparable results which are presented with the history of the animals, in Table 1. In positive reactions, microscopic examination showed clumps of cells sticking together in flat aggregates floating in the clear fluid.

From Table 1, it can be seen that the cells of Rabbits 16 and 20 react in a similar fashion with many of the sera in the group and may have common or identical antigens. The sera of Rabbits BO, 21, E6 and F2 have antibodies against the antigens on the red cells of Rabbits 16 and 20. As red cells of Rabbit $B O$ react with the sera of Rabbits 20 and 16 , the $B O$ cells definitely possessed different antigens from those present on cells of Rabbits 16 and 20. The cells of Rabbits 16 and 20 were selected for further study as they appeared to possess the same antigens.

After blood typing with anti-A, $-\mathrm{D}$ and $-\mathrm{F}$ immune sera, the results drawn from cross matching were found to be compatible. The cells of Rabbits 16 and 20 possessed $F$ antigen and lacked $A$ antigen. The presence of other antigens on these cells, however, could not be ruled out. For example, Rabbits G3 and 23 possessed FD antigen on their cells (see Table 1). Their sera could not have anti-F and anti-D agglutinins. The cells of $\mathrm{G} 3$ and 23 did not possess $\mathrm{A}$ antigen. Their sera had anti-A agglutinins and gave a positive reaction with the 16 and 20 cells which lacked $A$ antigen ( $F$ antigen). Some antigen other than $A, D$, and $F$ was, therefore, present on the 16 and 20 cells. 
Ordinary agglutination reaction of rabbit spermatozoa with the rest of the sera of the group

If the common antigen was present on the spermatozoa and cells, the corresponding isohaemagglutinin in the normal serum would agglutinate the spermatozoa. A pattern of agglutination similar to that obtained from cross matching would be expected if common antigens existed. The pattern of agglutination of spermatozoa with the tested sera did not tally exactly with that obtained with red cells. The common antigens between the two kinds of cells may have been absent. The sera that agglutinated red cells did not agglutinate spermatozoa, but some sera gave a positive reaction with spermatozoa only, some with red cells only, and some with both.

TABLE 1

CHARAGTERISTIGS OF INDIVIDUAL RABBITS AND THEIR BLOOD GROUP REAGTIONS

\begin{tabular}{|c|c|c|c|c|c|c|}
\hline \multirow[b]{2}{*}{ Rabbit } & \multirow[b]{2}{*}{$\begin{array}{l}\text { Coat } \\
\text { colour }\end{array}$} & \multirow[b]{2}{*}{ Sex } & \multirow[b]{2}{*}{$\begin{array}{c}\text { Age } \\
(\text { days })\end{array}$} & \multirow[b]{2}{*}{$\begin{array}{l}\text { Blood } \\
\text { type } \\
(H g \\
\text { system } \\
\text { only })\end{array}$} & \multicolumn{2}{|c|}{ Results of cross matching } \\
\hline & & & & & $\begin{array}{c}\text { Positive reaction of cells } \\
\text { of the animal with the } \\
\text { serum of: }\end{array}$ & $\begin{array}{l}\text { Positive reaction } \\
\text { of the serum of } \\
\text { the animal with } \\
\text { the cells of: }\end{array}$ \\
\hline $\begin{array}{c}18 \\
\text { E6 } \\
6 \\
\text { F2 } \\
\text { GH } \\
\text { G3 } \\
23 \\
9 \\
17 \\
\text { BO } \\
20 \\
4 \\
\mathrm{~J} 4 \\
21 \\
\mathrm{C} 1 \\
\mathrm{~A} 6 \\
\mathrm{E} 4 \\
16\end{array}$ & $\begin{array}{l}\text { BW } \\
\text { BL } \\
\text { ALB } \\
\text { BW } \\
\text { ALB } \\
\text { ALB } \\
\text { BW } \\
\text { ALB } \\
\text { BW } \\
\text { ALB } \\
\text { BW } \\
\text { ALB } \\
\text { BW } \\
\text { BW } \\
\text { ALB } \\
\text { ALB } \\
\text { BL } \\
\text { BW }\end{array}$ & $\begin{array}{l}9 \\
+ \\
+ \\
+ \\
+ \\
+ \\
+ \\
+ \\
+ \\
+ \\
+ \\
+ \\
0 \\
0 \\
0 \\
0 \\
0 \\
0 \\
0 \\
0 \\
0 \\
0 \\
0 \\
0 \\
0 \\
0 \\
0 \\
0 \\
0 \\
0\end{array}$ & $\begin{array}{l}604 \\
357 \\
605 \\
387 \\
930 \\
930 \\
604 \\
605 \\
604 \\
500 \\
604 \\
505 \\
347 \\
575 \\
605 \\
450 \\
357 \\
570\end{array}$ & $\begin{array}{l}\text { D } \\
\text { A } \\
\text { F } \\
\text { D } \\
\text { F } \\
\text { FD } \\
\text { FD } \\
\text { A } \\
\text { A } \\
\text { D } \\
\text { F } \\
\text { A } \\
\text { A } \\
\text { A } \\
\frac{\text { F }}{\text { F }}\end{array}$ & $\begin{array}{l}\mathrm{J} 4 \\
4,21 \\
4,21 \\
\frac{4}{-} \\
= \\
\overline{-} \\
\text { BO, E6, J4, 21, F2, 23, 9, G3 } \\
\text { Dead } \\
= \\
\overline{-} \\
\text { Dead } \\
\text { BO, E6, 21, G3, J4, } 23\end{array}$ & $\begin{array}{l}\frac{16}{\overline{16}}, 20 \\
16,20 \\
\overline{16}, 20 \\
20 \\
\frac{20}{20}, 16,4, \mathrm{E} 4,21 \\
\overline{\text { Dead }} \\
20 \\
20,4, \mathrm{E} 4,16 \\
\overline{-} \\
\text { Dead } \\
\text { F2 }\end{array}$ \\
\hline
\end{tabular}

$\mathrm{BW}=$ Black and White $\mathrm{BL}=\mathrm{Black} ; \mathrm{ALB}=$ Albino. $-=$ negative reaction with all animals.

It was persistently found that the direct control slides with spermatozoa and autologous serum showed positive agglutination (Padma, 1968).

Absorption of sera with red cells and spermatozoa of Rabbits 16 and 20

Sera from Rabbits BO and G3 were absorbed with red cells and spermatozoa from Rabbit 16, while sera from Rabbits BO, F2, and 9 were absorbed with cells and spermatozoa from Rabbit 20 . The positive reaction given by these sera with the spermatozoa or red cells of Rabbits 20 and 16 was not removed by absorption of the serum with either type of antigen. This suggested that the red cell antigens were independent of sperm antigens and had no common units. 
Mixed agglutination tests

To confirm the absence of a common antigen, an attempt was made to achieve mixed agglutination of the spermatozoa and red cells of Rabbit 20 with sera of Rabbits BO and F2. Mixed agglutination of both red cells and spermatozoa together was not observed and the sperm agglutination (head-to-head type) was found to be independent of the red cell aggregation. This occurred with natural agglutinins as well as with specific immune anti-A -D and -F sera against all the seven semen samples tested-BO, 20, J4, 21, C1, A6 and 16.

\section{DISCUSSION}

The isoantigens of mammalian spermatozoa have been studied by many workers in experiments both in vitro and in vivo, and examinations have also been carried out on the relationship of spermatozoa with homologous erythrocytic antigens and their impact on fertility in those animals which were hyperimmunized with spermatozoa. In human beings where a positive relationship between the erythrocytic antigens and the spermatozoa was established, Matsunaga \& Hiraizumi (1962) reported a statistically significant correlation between infertility and blood group incompatibility. The present study demonstrates that there is no common antigen between the red cell antigen and homologous spermatozoa in rabbits. The natural isohaemagglutinins detected by cross matching as well as the specific immune haemagglutinins failed to show a common antigen between the red cells and the spermatozoa. Cohen \& Tissot (1965) have noted that so far five blood group systems $(\mathrm{Hg}, \mathrm{Hb}, \mathrm{Hc}, \mathrm{He}$ and $\mathrm{Hh}$ ) possessing a total of sixteen antigenic factors can be shown to be present in rabbits. Only three immune sera were available for the three major isohaemagglutinogens of the $\mathrm{Hg}$ system (A, D and F antigens). It is not known whether antibodies against all the sixteen isoantigens are present as natural isohaemagglutinins in the normal serum. Assuming that they are, all the known sixteen isohaemagglutinins, as well as the unknown, would react in cross matching. If all these antigens were detected in the present study, then they were also shown to be absent on the spermatozoa. It was clear that the erythrocytic antigens $A, D$ and $F$ were definitely absent on the spermatozoa of the corresponding male.

It is only possible to speculate at this juncture on the reasons for the absence of erythrocytic antigens on spermatozoa in rabbits. It is known that those human individuals who possess a dominant secretor gene, either in homozygous or in heterozygous condition, secrete their blood group substances in their body fluids (Edwards et al., 1964). These authors further reported that only such secretors possessed the common antigen between their red cells and spermatozoa while the non-secretors did not. When the blood group substance was not secreted into the body fluids, it could not be acquired either by the red cells or by the spermatozoa. In fact, Stormont (1949) was able to convert J-negative erythrocytes in cattle into positive cells for this blood factor by incubating the cells in plasma containing the $\mathrm{J}$ substance. From the available literature and evidence presented here, it appears that this group of rabbits may have been lacking the secretor genes for these antigens. 


\section{ACKNOWLEDGMENTS}

The author wishes to thank Dr K. K. Iya for suggesting the problem. She also gratefully acknowledges the kind help and keen interest of Dr C. P. Anantha Krishnan and Dr M. Bhimsena Rao. Grateful thanks are also due to Professor G. Cohen of Western Reserve University, Gleveland, Ohio, U.S.A., for kindly supplying the specific rabbit blood typing sera, anti-A, -D and -F immune sera. The author gratefully acknowledges the technical assistance of $\mathrm{Mr} \mathrm{T}$. P. Suresh and Dr T. V. Kumar in collecting blood and semen from rabbits and cattle. Thanks are also due to Professor V. Gopal Rao, for critical reading of the manuscript and advice.

The research work presented here was carried out while the author was a Pool Officer (CSIR) at National Dairy Research Institute, Adugodi, Bangalore-30 from 1965 to 1967.

\section{REFERENGES}

Boetrcher, B. (1965) Human ABO blood group antigens on spermatozoa from secretors and nonsecretors. 7. Reprod. Fert. 9, 267.

Conen, G. \& Tissot, R. G. (1965) Blood groups in the rabbit. Two additional isoantibodies and the red cell/antigens they identify. F. Immun. 95, 148.

Coombs, R. R. A., Bedford, D. \& Rouillard, L. M. (1956) A and B blood group antigens on human epidermal cells. Lancet, i, 461.

Docton, F. L., Ferguson, L. C., Lazear, E. J. \& Ely, F. (1952) The antigenicity of bovine spermatozoa. F. Dairy Sci. 35, 706.

Edwards, R. G., Ferguson, L. C. \& Coombs, R. R. A. (1964) Blood group antigens on human spermatozoa. 7. Reprod. Fert. 7, 153.

Kabat, E. A. (1956) Blood Group Substances, Their Chemistry and Immunochemistry. Academic Press, London.

LANDSTEInER, K. \& Levine, P. (1926) On group specific substances in human spermatozoa. $\mathcal{F}$. Immun. 12, 415.

MacrRone, C. \& Walton, A. (1938) Fecundity of male rabbits as determined by 'dummy matings'. J. agric. Sci., Camb. 28, 122.

Majsky, A. \& Hraba, P. (1960) Demonstration of $\mathrm{D}\left(\mathrm{Rh}_{\mathbf{0}}\right)$ agglutinogens in human spermatozoa. Folia biol., Praha, 6, 342.

MAtousek, J. (1964) Antigenic characteristics of spermatozoa from bulls, rams and boars. I. Erythrocytic antigens in bull spermatozoa. 7. Reprod. Fert. 7, 1.

Matsunaga, E. \& Htraizumi, Y. (1962) Prezygotic selection in ABO blood groups. Science, N.Y. 135, 432.

PADMA, M. C. (1968) Some features of the isoantigens of cattle and rabbit spermatozoa. D.Sc. thesis, University of Mysore, India.

PADMA, M. C. (1969) Relationship of blood group antigens in cattle to homologous spermatozoan antigens as detected by natural agglutinins. Indian 7. exp. Biol. 7, 246.

Schiff, F. \& Boyd, W. C. (1942) Blood Grouping Technic, a Manual for Clinicians, Serologists, Anthropologists, Students of Legal and Military Medicine. Interscience Publishers.

Schmidt, D. O. (1960) Blood group antigens in bull spermatozoa. Proc. VIII Int. Blood Group Congr., Edinburgh.

Smith, A. U. (1949) Some antigenic properties of mammalian spermatozoa. Proc. R. Soc. B, 136, 46.

Stormont, C. (1949) Acquisition of J substance by the bovine erythrocyte. Proc. natn Acad. Sci. U.S.A. $35,232$. 